\title{
ANALISIS TINDAK TUTUR PADA BAHASA IKLAN PRODUK MI INSTAN INDOMIE DI TELEVISI
}

\author{
Nurul Mutiah Romadhani ${ }^{1)}$, Rose Junieles ${ }^{2)}$ \\ ${ }^{1}$ Institut Agama Islam Negeri Surakarta \\ email: nurulromadhani371@gmail.com \\ ${ }^{2}$ Institut Agama Islam Negeri Surakarta \\ email: mbkrosejunia28@gmail.com
}

\begin{abstract}
Abstrak
Peristiwa tindak tutur biasa digunakan untuk mengetahui sebuah informasi tertentu, peristiwa tindak tutur di tandai dengan adanya penutur dan mitra tutur. Permasalahan yang dikaji dalam analisis ini ialah tindak tutur, lokusi, ilokusi dan perlokusi yang terdapat dalam iklan produk mi instan indomie di televisi. Penelitian ini penting dilakukan karena dalam sebuah produksi, iklan merupakan salah satu aspek yang penting untuk mendongkrak penjualan produk. Pelaksanaan penelitian ini menggunakan metode deskriptif kualitatif dengan pendekatan pragmatik, data dari penelitian ini yaitu bahasa iklan mi instan indomie yang ditulis lalu dianalisis. Teknik pengumpulan data yang digunakan teknik mengamati dan catat. Data diperoleh dengan cara melihat dan mengamati iklan mi instan indomie, kemudian mencatat data dari iklan yang ingin diteliti. Hasil dari penelitian ini menujukan bahwa adanya peristiwa tindak tutur lokusi, tindak tutur ilokusi serta tindak tutur perlokusi.
\end{abstract}

Kata Kunci: iklan, mi instan indomie, tindak tutur, pragmatik.

\begin{abstract}
Speech acts are usually used to find out certain information, speech acts are marked by speakers and speech partners. The problems examined in this analysis are speech acts, locution, illocution and percocution contained in the advertisement of instant noodle products on television. This research is important because in a production, advertising is one of the important aspects to boost product sales. The implementation of this research uses a descriptive qualitative method with a pragmatic approach, the data from this research are the language of instant noodle indomie language written and then analyzed. Data collection techniques used observation and record techniques. Data is obtained by viewing and observing instant noodle advertisements, then recording data from the advertisements that are to be investigated. The results of this study address the locus of speech acts, illocutionary acts and speech acts of speech.
\end{abstract}

Keywords: advertising, indomie instant noodles, speech acts, pragmatics.

\section{PENDAHULUAN}

Bahasa memiliki fungsi sebagai alat komunikasi yang digunakan manusia untuk mengetahui sebuah informasi tertentu, apapun informasinya memerlukan bahasa sebagai perantara dan disinilah bahasa memainkan perannya sebagai alat komunikasi (Saputri dkk, 2014) informasi bisa didapatkan manusia dengan melakukan aktifitas tindak tutur. Bahasa dalam kehidupan sehari-hari selalu berkembang mengikuti perubahan zaman, bahasa merupakan alat komunikasi yang dapat mengalami perubahan dengan mengikuti perkembangan zaman, perubahan tersebut dapat berupa perubahan makna ataupun bentuk katanya (Susilawati dan yunus, 2017: 4). Perubahan bahasa yang terjadi dapat menimbulkan ragam bahasa baru sesuai dengan fungsi bahasa yang seharusnya, adanya teknologi dan internet menjadi salah satu faktor yang membuat ragam bahasa baru tersebut tersebar secara cepat.

Teknologi merupakan salah satu alat penunjang kehidupan manusia, dengan adanya teknologi kehidupan manusia mengalami kemajuan yang sangat pesat. Teknologi merupakan bentuk proses yang meningkatkan nilai tambahan, berupa menggunakan dan menghasilkan suatu produk tertentu (Miarso, 2007). Salah satu teknologi yang ikut menyebarkan ragam bahasa baru yaitu media massa, media elektronik dan media sosial. Kehadiran teknologi ditengah masyarakat sekarang ini membawa dampak yang besar terhadap perkembangan pemasaran serta 
ekonomi global. Tidak bisa dipungkiri dengan adanya teknologi dunia pemasaran menjadi lebih canggih dan dapat tersebar keseluruh penjuru dunia. Pembuatan iklan saat ini mengalami kenaikan yang cukup pesat, dengan adanya media-media yang memadahi pemasaran produk menjadi lebih beragam.

Televisi merupakan salah satu media elektronik yang hingga saat ini masih banyak diminati oleh masyarakat, televisi tidak hanya berfungsi sebagai media hiburan namun juga berfungsi sebagai media informasi. Televisi menjadi salah satu media yang digunakan dalam industri periklanan untuk menarik minat masyarakat terhadap sebuah barang atau jasa. Karena pada dasarnya televisi memiliki kelebihan untuk mendemonstrasikan produk kepada masyarakat secara bersamaan dengan menampilkan visual dan audio yang mampu menyita perhatian masyarakat luas. Menurut Morissan dalam (Prasetya dan Samhati, 2017) televisi mempunyai kelebihan dibandingkan media lain yang mampu mencakup daya jangkau luas, selektivitas, mampu menyesuaikan keadaan dengan cepat, kreatif serta prestise dalam waktu tertentu. Sehingga keberadaan televisi menjadi ruang kreasi untuk produsen produk yang ingin mempromosikan suatu produknya melalui sebuah iklan.

Iklan merupakan salah satu bentuk komunikasi antara produsen dan konsumen dalam hal pemasaran. Oleh karena itu sebuah iklan harus memiliki daya tarik yang kuat dan juga unik untuk menarik perhatian masyarakat luas. Tidak hanya unik dan menarik namun bahasa yang digunakan dalam iklan harus memenuhi syarat seperti harus menggunakan kalimat persuasif, menggunakan diksi dan juga menggunakan kata yang tepat dan mudah dipahami oleh masyarakat luas. Cara produsen untuk mengelola iklan agar durasi waktu tepat dan tidak terlalu panjang yaitu menggunakan bahasa yang singkat dan sederhana namun maksud dari iklan harus tetap tersampaikan kepada penonton (Prasetya dan samhati, 2017). Hal inilah yang menjadi tantangan untuk produsen iklan karena dalam waktu yang singkat bahasa iklan harus masuk kedalam ingatan para penonton.

Para produsen produk tidak pernah kehabisan akal untuk memunculkan iklan yang lebih baru dan mudah diterima masyarakat, setiap produsen produk selalu memperbarui bahasa dan juga tampilan iklan agar para konsumen tidak mudah bosan dengan produk tersebut. Memunculkan artis baru, mengganti bahasa iklan, menyajikan visual produk yang lebih menarik, dan menyesuaikan dengan keadaan saat ini merupakan sebuah cara untuk memperbarui iklan. Bahasa iklan yang menarik serta tampilan visual yang unik ternyata menjadi daya tarik tersendiri bagi konsumen sehingga hal tersebut berpengaruh terhadap daya beli konsumen pada sebuah produk. Ternyata bahasa iklan dan visualnya mempengaruhi dari berbagai macam segi.

Bahasa yang dikemas dengan baik dapat menjadikan iklan tersebut menarik dan menyita banyak perhatian penonton, contohnya saja pada iklan produk instan seperti kopi, mi, bubur, bumbu masakan hingga sosis yang siap makan. Hampir setiap saat iklan produk instan tersebut muncul dilayar kaca karena pada saat ini manusia membutuhkan sesuatu yang mudah, praktis dan juga murah. Cara pemasaran produk ini juga beragam ada yang hanya menggunakan narator atau dilakukan dengan aktivitas tindak tutur.

Tindak tutur merupakan sebuah kegiatan yang melibatkan beberapa orang untuk mendapatkan suatu informasi yang diinginkan, menurut Searle (dalam Rusminto, 2010: 22) tindak tutur merupakan ilmu yang mengkaji makna bahasa berdasarkan hubungan dan tindakan yang dilakukan oleh penutur. Tindak tutur menjadi pilihan yang paling banyak diminati dalam pembuatan iklan. Karena dalam aktifitas tersebut bahasa yang digunakan menjadi lebih menarik dan pengekspresian dari ungkapan yang disampaikan terlihat apaadanya. Penelitian ini dirasa penting untuk dilakukan karena bahasa menjadi objek yang penting untuk pemasaran suatu produk, selain 
itu penelitian dapat berguna untuk menbambah wawasan tentang aktifitas tindak tutur dalam iklan.

Sebelumnya juga ada beberapa penelitian yang membahas tentang tindak tutur bahasa yang terdapat pada iklan. Pertama dibahas oleh Wafratur Rochmah dalam jurnal Bahasa dan Satra Indonesia volume 6 no 1 tahun 2017 dengan judul "Analisis Tindak Tutur Dalam Iklan Produk Kecantikan Di Televisi" lalu oleh Yuni Anjani dalam bentuk skripsi Universitas Muhammadiyah Surakarta pada tahun 2016 dengan judul "Tindak Tutur Dalam Wacana Iklan Berbahasa Indonesia di Televisi : Sebuah Kajian Pragmatik" dan selanjutnya oleh Rian Andri Prasetya dalam jurna JSimbol pada tahun 2017 dengan judul "Tindak Tutur Pada Iklan Produk Makanan Cepat Saji Di Televisi dan Implikasinya" dari ketiga penelitian tersebut menjabarkan bahwa pengaruh tindak tutur dan bahasa sangat besar untuk pemasaran suatu produk.

Hal tersebutlah yang mendasari peneliti melakukan penelitian tentang tidak tutur bahasa iklan yang terdapat pada produk mie instan indomie di televisi. Tujuan yang ingin dicapai dari penelitian ini ialah pengelompokan iklan terhadap tindak tutur lokusi, ilokusi dan perlokusi. Penelitian ini menggunakan pendekatan pragmatik sebagai usaha untuk mengetahui aktifitas tindak tutur lokusi, ilokusi dan perlokusi yang terdapat dalam iklan. Pragmatik dipilih karena cabang ilmu bahasa yang mempelajari tentang struktur bahasa, dan pragmatik dapat mengkaji bahasa yang digunakan dalam aktifitas sehari-hari. Menurut Djajasudarma dalam (Anjani, 2016) pragmatik merupakan sebuah ilmu bahasa yang mempelajari tentang penggunaan bahasa masyarakat.

\section{KAJIAN LITERATUR}

Menurut Wiryotinoyo

(2006:153)

Pragmatik adalah studi makna yang berkaitan dengan situasi ujar (SU). Sementara itu, Levinson dikutip oleh Zamzami (2007:20) menyebutkan bahwa pragmatik merupakan kajian pemakaian bahasa yang tidak terlepas dari konteks. Yule (1996: 3) juga menyatakan bahwa pragmatik mengkaji makna kontekstual, yaitu adanya lebih banyak makna yang dikomunikasikan melebihi apa yang sebenarnya diujarkan. Berkaitan dengan hal tersebut, Searle, Kiefer, dan Bierwisch (dalam Nadar, 2009: 5) menyatakan bahwa pragmatik adalah suatu cabang ilmu bahasa yang memiliki topik, yaitu beberapa aspek yang tidak dapat dijelaskan dengan acuan langsung pada kondisi sebenarnya dari kalimat yang dituturkan. Dengan kata lain dapat dikatakan bahwa makna suatu tuturan tidak dapat diartikan begitu saja, tuturan harus dikaitkan dengan konteks-konteks yang melatarbelakangi terbitnya tuturan tersebut . Dari berbagai pendapat di atas dapat disimpulkan bahwa pragmatik merupakan suatu cabang ilmu bahasa yang berkaitan dengan situasi ujar dan tidak pernah terlepas dari konteks.

Tindak tutur merupakan salah satu aspek dalam kajian pragmatik. Pragmatik mengkaji bahasa dalam pemakaian yang nyata dalam masyarakat bahasa yang tidak dapat dilepaskan dari konteks dan situasi. Zamzami (2007: 3839) menyatakan bahwa tindak bahasa merupakan kegiatan berbicara dalam suatu bahasa. Tindak tutur merupakan kegiatan berkomunikasi antara penutur dan petutur dengan menggunakan media bahasa. Tindak tutur yang disebut tindak berbahasa oleh Zamzami adalah bagaimana seseorang melakukan sesuatu yang berwujud bahasa. Oktavianus (2006: 70) menyatakan bahwa tindak tutur adalah bagian dari cabang ilmu linguistik atau ilmu bahasa yang mempelajari tentang perilaku komunikasi interpersonal pemakai bahasa. Bahasa yang digunakan sebagai media komunikasi antara satu orang dengan orang yang lainnya dapat berupa tuturan yang memiliki makna pernyataan, pertanyaan, dan perintah. Definisi lainnya mengenai tindak tutur dinyatakan oleh Yule dalam Wiyatasari (2015: 46) tindak tutur adalah tindakan-tindakan yang ditampilkan 
lewat tuturan. Menurut Yule (2006: 83) mengatakan tindakan yang ditampilkan dengan menghasilkan suatu tuturan akan mengandung tiga tindak yang saling berhubungan. Pertama adalah tindak lokusi, yang merupakan tindak dasar tuturan atau menghasilkan suatu ungkapan linguistik yang bermakna. Tindak ilokusi ditampilkan melalui penekanan komunikatif suatu tuturan. Tindak perlokusi menciptakan tuturan yang memiliki fungsi tanpa memaksudkan tuturan itu memiliki akibat.

Media massa merupakan sarana untuk memberitahukan suatu pesan iklan kepada khalayak umum. Televisi merupakan salah satu media yang menyiarkan periklanan. Hal ini disesuaikan pada pendapat Atmadi (1985: 183) bahwa pesan iklan dapat disebarluaskan melalui berbagai media yang meliputi radio, televisi, bioskop, surat kabar, majalah, papanpapan iklan, pos langsung, selebaran, pengantar penawaran, dan alat peraga. Wacana iklan di media televisi dalam menyampaikan informasi mengandalkan audio, visual dan gerak. Hal ini sesuai pendapat Suyanto (2005: 5) Iklan televisi mempunyai cakupan, jangkauan dan repitisi yang tinggi dan dapat menampilkan pesan multimedia (suara, gambar, dan animasi) yang dapat mempertajam ingatan. Menurut Riyanto (dalam Hermintoyo dan Suyanto, 2002: 9) iklan merupakan pesan yang lebih diarahkan untuk membujuk seseorang atau sekelompok orang agar mau membeli barang atau jasa yang dikomunikasikan. Dunn dan Barban, sebagaimana dikutip oleh Widyatama (2007: 15) menjelaskan bahwa iklan merupakan bentuk kegiatan komunikas nonpersonal yang disampaikan lewat media dengan membayar ruang yang dipakainya untuk menyampaikan pesan yang bersifat membujuk (persuasif) kepada konsumen oleh perusahaan, lembaga nonkomersial, maupun pribadi yang berkepentingan. Dari berbagai pendapat di atas dapat disimpulkan bahwa iklan merupakan bentuk komunikasi antara produsen dengan konsumen untuk memperkenalkan atau menawarkan sutu produk kepada khalayak umum.

\section{METODE PENELITIAN}

Penelitian ini tergolong ke dalam penelitian kualitatif yang bersifat deskriptif. Peneliti menggunakan pendekatan kualitatif karena data yang berupa bentuk-bentuk verbal bahasa yaitu berupa tuturan-tuturan dari mitra tutur iklan mi instan indomie di televisi. Sesuai dengan pendapat Bogdan dan Taylor (dalam Moleong,2012: 4), penelitian kualitatif sebagai prosedur penelitian yang menghasilkan data deskriptif berupa kata-kata tertulis atau lisan dari orang-orang dan perilaku yang diamati. Menurut Arikunto (2010: 3) pendekatan penelitian ini menggunakan pendekatan kualitatif karena hasil analisis datanya tidak berupa data statistik karena data penelitian ini tidak dikuantifikasi melainkan penjabaran berupa kalimat atau percakapan iklan yang dilakukan mitra tutur dalam iklan mi instan indomie di televisi. Menurut Pangaribuan (2008:14), penelitian kualitatif berupaya menemukan hipotesis, yaitu kaidah-kaidah yang ada dalam realitas yang diamati dengan mengamati iklan mi instan indomie di televisi.

Subjek penelitian ini adalah iklan mi instan indomie. Objek penelitian ini adalah tindak tutur lokusi, ilokusi, dan perlokusi yang dituturkan dalam percakapan iklan mi instan indomie. Penelitian ini dilakukan dengan mengamati vidio iklan mi instsn indomie di televisi. Data yang digunakan pada penelitian ini berupa kata-kata, cuplikan dialog, dan kutipan-kutipan kalimat yang berisi tuturan lokusi, ilokusi, dan perlokusi yang terdapat dalam iklan mi instan indomie. Pengumpulan data dalam penelitian ini dilakukan dengan metode simak dengan teknik simak bebas libat cakap (SBLC) karena penulis tidak terlibat dalam dialog (Sudaryanto, 2015: 242).

Teknik pemerolehan data berikutnya adalah teknik rekam dan catat yang merupakan teknik lanjutan. Teknik rekam yang dimaksud dapat lebih beraneka dengan hasil yang lebih seksama, meliputi baik tindakan ujaran yang 
mampu didengarkan maupun tingkah laku dan perbuatan lain yang mampu dilihat, baik yang verbal maupun non verbal dalam penayangan iklan. Instrumen yang digunakan dalam penelitian ini adalah penulis sendiri dibantu dengan alat berupa alat tulis, buku-buku teori tindak tutur, dan iklan mi instan indomie di televisi. Metode yang digunakan dalam menganalisis data adalah metode padan dengan teknik daya pilah pragmatis yang alat penentunya mitra tutur karena tuturan yang dituturkan menimbulkan reaksi tindakan tertentu dari mitra tutur. Dalam penelitian ini penulis menggunakan teknik penyajian hasil analisis informal. Teknik informal merupakan penyajian hasil analisis data yang diperoleh dengan menggunakan kata-kata biasa tanpa lambang-lambang (Sudaryanto, 2015: 241)

\section{HASIL DAN PEMBAHASAN}

Dari data yang sudah kami dapatkan, ada setidaknya tiga data untuk tindak tutur lokusi, satu data tindak tutur ilokusi dan tiga data untuk tindak tutur perlokusi. Berikut hasil data yang sudah dilampirkan

a. Tindak Tutur Lokusi

Iklan produk instan yang terdapat dalam mi instan indomie, ditemukan data yang berisi tindak tutur lokusi yang bermaksud menyatakan dan menginformasikan sesuatu. Seperti pada data sebagai berikut.

1) Konteks:

Pada iklan mi instan Indomie yang terdapat pada televisi menampilkan visual mie yang sedang di masak lalu beralih pada ayam geprek dan sambal matah, lalu beralih pada sekumpulan pemuda yang sedang makan di sebuah bazar makanan. Munculah seorang laki-laki dengan membawa piring berisikan makanan.

Laki-laki 1: Dari mana?

Laki-laki 2: Dari Indomie mi goreng aceh

Laki-laki 3: Ah A A Aceh

Wanita 1 dan 2: Sampai pedas Indomie goreng ayam geeee

Laki-laki 4: geeeprek
Laki-laki 1,2,3: Kekayaan pedas Indonesia dari lidah kena ke hati

Laki-laki 4: Pedasnya Indonesia banget

Semua: Indomie seleraku!

Dalam tuturan di atas terdapat bukti bahwa iklan mi instan indomie memiliki tindak tutur lokusi yang bermaksud menyatakan dan menginformasikan. Pada ucapan laki-laki 1,2 dan 3 menyatakan bahwa "Kekayaan pedas Indonesia dari lidah kena kehati" dan dilanjutkan oleh kalimat laki-laki 4 "Pedasnya Indonesia banget" pada kalimat tersebut menyatakan bahwasannya mi indomie memiliki varian rasa dari masakan indonesia yang terkenal akan rasa pedasnya. Rasa pedas yang tercipta dari beberapa rempah di indonesia sehingga menghasilkan rasa pedas yang hampir mirip dengan makanan aslinya namun dikemas dalam produk $\mathrm{mi}$ instan indomie.

2) Konteks:

Pada iklan mi instan indomie yang terdapat pada televisi menampilkan 3 laki-laki dan 1 perempuan sedang latihan bernyanyi di studio musik.

Laki-laki 1: Break duku yuk! (Kemudian mereka berempat turun menuju ruang tamu.)

Perempuan: Ech pada laper yaa. mau dimasakin ayam apa yang spesial?

Laki-laki 1,2,3: Yang spesial (Perempuan 1 memasak di dapur.

Narator: Inilah rasa baru indomie goreng rendang pertama dengan rasa daging rendang yang diolah dengan bumbu rendang asli hadirkan kelezatan dengan aroma menggoda.

Perempuan 1 dan 3 laki-laki tersebut menikmati mi goreng rendang di ruang tamu.

Perempuan 1: Spesial kan?

Laki-laki 2: Enak... enak...

Laki-laki 1,3: Ini baru rendang

Narator: Baru indomie goreng rendang.

Dalam tuturan di atas terdapat bukti bahwa iklan mi instan indomie memiliki tindak tutur lokusi yang bermaksud menyatakan dan menginformasikan. Pada ucapan narator "Inilah rasa baru indomie goreng rendang 
pertama dengan rasa daging rendang yang diolah dengan bumbu rendang asli hadirkan kelezatan dengan aroma menggoda" pada kalimat tersebut menyatakan dan menginformasikan bahwa indomie goreng rendang adalah rasa terbaru dari mi indomie, yang memiliki varian rasa rendang pertama dengan daging rendang yang diolah dengan bumbu rendang asli, dengan kelezatan dan aroma yang menggoda.

3) Konteks :

Pada iklan mi instan indomie yang terdapat pada televisi menampilkan laki-laki dan perempuan sedang duduk di kantin kampus.

Laki-laki 1: Kamu tahu gak datangnya cinta?

Perempuan 1: Dari mana?

Laki-laki 1: Dari mata turun ke hati

Laki-laki 2: (Tiba-tiba datang) Ech kalau pedas datangnya dari mana?

Laki-laki 2: Dari marah turun ke sini (sambil menunjukkan indomie goreng sambal marah)

Narator: Baru nih indomie goreng rasa sambal marah eesss hahh dengan irisan bawang dan cabe indomie goreng sambal marah seger pedesnya bikin semangat.

Dalam tuturan di atas terdapat bukti bahwa iklan mi instan indomie memiliki tindak tutur lokusi yang bermaksud menyatakan dan menginformasikan. Pada ucapan narator "Baru nih indomie goreng rasa sambal matah eesss hahh dengan irisan bawang dan cabe indomie goreng sambal matah seger pedesnya bikin semangat" pada kalimat tersebut menyatakan dan menginformasikan kepada penonton bahwa indomie goreng rasa sambal marah adalah variasi baru dengan irisan bawang dan cabe yang membuat pedasnya segar dan bikin semangat saat menikmatinya.

\section{b. Tindak Tutur Ilokusi}

Iklan produk instan yang terdapat dalam mi instan indomie, ditemukan data yang berisi tindak tutur Ilokusi yang bertujuan memberikan efek atau mendorong mitra tutur untuk melakukan sesuatu. Seperti pada data sebagai berikut.

1) Konteks :
Pada iklan mi instan Indomie yang terdapat pada televisi menampilkan seorang wanita yang sedang berpikir untuk memesan sesuatu di jam makan siang pada seorang laki-laki yang sedang berjalan di depannya.

Wanita: Mas pesen makan dong, pengin rasa daging dan pedes. Mas ada aroma bakarnya ya!

Laki-laki: Oke mbak, oke emmm

Wanita: Mas!!

Laki-laki: Eehhhh

Wanita: Tapi mi ya!!

Laki-laki: Iya, heem

Kor: Ehh apaan tuh? Aromanya, mau dong mau dong

Narator: Ini Indomie goreng rasa iga penyet baru, rasa penyetnya dasyat

Wanita: Wahh, gurih krenyes penyetnya, pedes!!

Narator: Indomie goreng rasa iga penyet. Dahsyat rasanya!!

Dari data tuturan diatas dapat disimpulkan bahwa wanita yang sedang memesan makanan tersebut menginginkan adanya efek timbal balik dari sang mitra tutur. Terdapat dalam kalimat "Mas pesen makan dong, pengin rasa daging dan pedes. Mas ada aroma bakarnya ya!" wanita tersebut menginginkan sebuah makanan yang rasanya seperti daging, pedas dan ada aroma bakarnya namun dia tidak menyebutkan secara spesifik makanan apa yang di inginkan. Lalu pada kalimat "Tapi mi ya!!" sang wanita menginginkan makanan tersebut terbuat dari mi, tindakan yang diambil dari laki-laki tersebut ialah membawakan sebuah mi yang ada rasa dagingnya, terasa pedas dan beraroma bakar. Secara tidak langsung iklan tersebut menujukkan bahwa indomie iga penyet memiliki rasa yang hampir sama dengan makanan aslinya yaitu iga penyet.

c. Tindak Tutur Perlokusi

Iklan produk instan yang terdapat dalam mi instan indomie, ditemukan data yang berisi tindak tutur Perlokusi yang bermaksud untuk mendorong, membujuk dan memberikan efek 
agar para penonton membeli produk yang di iklankan. Seperti pada data sebagai berikut.

\section{1) Konteks:}

Pada tayangan iklan di televisi menampilkan lima pemuda terdiri dari tiga pria dan dua wanita. Dalam tayangan tersebut seorang pria berdiri sendiri dan berhadapan dengan keempat pemuda yang lain.

Laki-laki 1: Geeee

Laki-laki 2: Gerah?

Laki-laki 1: Geeee

Laki-laki 3: Getar?

Laki-laki 1: Geeee

Wanita 1 \& 2: Gemes?

Laki-laki 1: Indomiee ayam geprek

4 pemuda: Hype abis

Narator: Indomie hype abis ayam geprek kemasannya keren, kremesannya gress, pedas dan bawangnya bikin lo merem melek. Indomie hype abis ayam geprek. Gepreknya bikin semangat!!

Dalam data di atas terbukti bahwa iklan mie instan indomie memiliki aktivitas tindak tutur berupa perlokusi yang bermaksud untuk memberikan efek dan mendorong penonton agar memberi produk yang di iklankan. Pada tuturan narator yang menyatakan bahwa "Kremesnya gres" lalu "Pedas dan bawangnya bikin lo merem melek" merupakan tuturan yang dapat memberikan efek, bila penonton membeli indomie ayam geprek maka kremes yang terdapat dalam mie akan seperti ayam geprek yang asli, pedas dan bawangnya membuat siapa pun yang memakan mie tersebut akan membuat mata menjadi cerah karena efek pedas dan bawang yang terdapat dalam mie. Lalu pada kata "Gepreknya bikin semangat" mengartikan bahwa siapapun yang membeli indomie ayam geprek akan bertambah semangatnya. Ketiga hal tersebutlah yang memberikan efek dan mendorong pada penonton untuk membeli produk yang di iklankan.

2) Konteks :

Pada tayangan ikln televisi menampilkan visual mi indomie real meet peper chicken. Kemudian ada 1 perempuan sedang duduk di
Maja makan yang berada di dapur sambil menikmati mi indomie real meet peper chicken.

Narator: The new indomie real meet peper chicken itulah suara mata hati yang terbuka, nikmatnya blarrr, lembutnya mi kriting bikin lidah dancing tujuh kelililing, ditambah daging asli yang bikin body serasa flaying. The new indomie real meet. You deserve it.

Dalam data di atas terbukti bahwa iklan mie instan indomie memiliki aktivitas tindak tutur berupa perlokusi yang bermaksud untuk memberikan efek dan mendorong penonton agar memberi produk yang di iklankan. Pada tuturan narator yang menyatakan bahwa "nikmatnya blarr" lalu "lembutnya mi kriting bikin lidah dancing tujuh keliling" merupakan tuturan yang dapat memberikan efek bagi penonton bila membeli mi indomie real meet peper chicken akan menimati rasa enak yang begitu nikmat dan juga lembut mi kriting membuat lidah menari tujuh keliling hal ini menunjukkan efek yang sangat berpengaruh saat menikmati mi tersebut kita serasa menari tujuh keliling akibat rasa mi yang begitu lembut dan memanjakan lidah. Lalu pada kalimat "ditambah daging asli yang bikin body serasa flaying" merupakan tuturan yang dapat memberikan efek bagi penonton bila membeli mi indomie real meet peper chicken akan menikmati rasa mi yang ditambah dengan daging asli, yang membuat tubuh serasa terbang karena rasanya sangat enak dan nikmat saat memakannya.

3) Konteks :

Pada tayangan iklan di televisi menampilkan visual mi indomie hype abis kuah seblak hot jeletot yang disajikan di dalam mangkok sedang dinikmati oleh beberapa orang laki-laki dan perempuan, dengan ekspresi berkeringat dan kepedesan saat menikmatinya.

Narator: Indomie hype abis kuah seblak hot jeletot. Indomie seblak hot jeletot. Indomie seblak hot jeletot. Mi lebar plus ditambah krupuk seblak nyesss, hot aja hot jeletot enak 
pedes nya kuah gila sehhh. Indomie hype abis seblak hot jeletot.

Dalam data di atas terbukti bahwa iklan mi instan indomie memiliki aktivitas tindak tutur berupa perlokusi yang bermaksud untuk memberikan efek dan mendorong penonton agar memberi produk yang di iklankan. Pada tuturan narator yang menyatakan bahwa "mi lebar plus ditambah krupuk seblak nyesss" merupakan tuturan yang dapat memberikan efek bagi penonton bila membeli mi indomie hype abis kuah seblak hot jeletot akan menikmati mi yang lebar beda dari merek lainnya dan juga ditambah kerupuk seblak yang gurih dan renyah. lalu kalimat "hot aja hot jeletot enak pedesnya kuah gila sehh" merupakan tuturan yang dapat memberikan efek bagi penonton bila membeli mi indomie hype abis kuah seblak hot jeletot akan menikmati rasa pedas yang begitu pedas yang berasal dari bumbu cabe setengah sachet biar pedas nya hot aja atau pakai cabe satu sachet biar pedes nya hot jeletooootttt pedes kuahnya gilaa sehh saking pedas banget.

\section{KESIMPULAN}

Bedasarkan hasil penelitian Analisis Tindak Tutur Pada Bahasa Iklan Produk Mi Instan Indomie Di Televisi dapat disimpulkan bahwa adanya peristiwa tindak tutur lokusi, tindak tutur ilokusi, serta tindak tutur perlokusi. Tindak tutur lokusi bertujuan menyatakan dan menginformasikan sesuatu, tindak tutur ilokusi bertujuan memberikan efek atau mendorong mitra tutur melakukan sesuatu, tindak tutur perlokusi bertujuan mendorong, membujuk, dan memberikan efek agar penonton membeli produk yang diiklankan. Dari data yang sudah kami dapatkan, ada setidaknya tiga data untuk tindak tutur lokusi, satu data untuk tindak tutur ilokusi, dan tiga data untuk tindak tutur perlokusi.

\section{DAFTAR PUSTAKA}

Anjani, Yuni. 2016. Tindak Tutur Pada Wacana Iklan Berbahasa Indonesia Di
Televisi Sebuah Kajian Pragmatik. Surakarta : Universitas Muhammadiyah Surakarta.

Arikunto, Suharsimi. 2010. Dasar-Dasar Evaluasai Pendidikan. Bandung: Bumi Angkasa.

Arikunto, Suharsimi. 2010. Dasar-Dasar Evaluasai Pendidikan. Bandung: Bumi Angkasa.

Hermintoyo, Suyanto. 2002. "Citra Perempuan dalam Bahasa Indonesia: Studi Kasus Citra Perempuan dalam Penggunaan Bahasa Indonesia pada Iklan Majalah Femina dan Kartini”. Laporan Penelitian. Semarang: Fakultas Sastra Undip.

Miarso, 2007. Menyemai benih teknologi pendidikan. Jakarta: Pustekom Diknas.

Moleong, Lexy J. 2012. Metodologi Penelitian Kualitatif. Bandung: PT Remaja Rosdakarya.

Nazar, F.X. 2009. Pragmatik dan Penelitian Pragmatik. Yogyakarta: Graha Ilmu.

Oktavianus. 2006. Analisis Wacana Lintas Bahasa. Yogyakarta: Andalas University Press.

Pangaribuan, Tagor. 2008. Paradigma Baru. Yogyakarta: Graha Ilmu.

Prasetya, Rian Andri, dan Yunus. 2017. Tindak Tutur Pada Iklan Produk Makanan Cepat Saji Di Televisi Dan Implikasinya. JSimbol. No 1.

Rusminto, Nurlaksana Eko. 2010. Memahami Bahasa Anak-anak: Sebuah Kajian Analisis Wacana Panduan Bagi Guru, Orang Tua dan Mahasiswa Jurusan Bahasa. Bandar Lampung: Universitas Lampung. 
Saputri, Anil, Novia Juita, dan Ngusman. 2014. Tindak Tutur Direktif Dalam Iklan

Kartu GSM. Bahasa dan Sastra 2. Vol 2. No 4.

Susilawati, Erni, dan Yunus. 2017. Variasi Bahasa Dalam Novel Perempuan Karya Peyem. Jurnal Bastra. Vol 1. No 4

Suyanto, M. 2005. Pengantar Teknologi infomasi untuk bisnis. Yogyakarta: Andi.

Widyatama, Rendra. 2007. Pengantar Periklanan. Yogyakarta: Pustaka Book Publisher.

Wiryotinoyo, M. 2006. Analisis Pragmatik dalam Penelitian Bahasa. Malang: Universitas Negeri Malang.

Wiyatasari, Reny. 2015. Teknik Penerjemahan Tindak Tutur Direktif dalam Cerpen Doktor Sihir Kaya Iwaya Sazanami dan Larilah Melos Karya Dazai Osamu. Jepang: Jurnal Bahasa Sastra dan Budaya. Volume 4, No.2 hal. 4255.

Yule, George. 1996. Pragmatik. Yogyakarta: Pustaka Pelajar.

Zamzami. 2007. Kajian Sosiopragmatik. Yogyakarta: Cipta Pustaka. 